\title{
Vitamin D status in hospitalized patients with chronic obstructive pulmonary disease
}

\author{
Nurdan KÖKTÜRK ${ }^{1}$ \\ Esra Meltem KOÇ ${ }^{2}$ (ID) \\ Tuğba KÖRLÜ AKKALE ${ }^{3}$ \\ (ID) \\ Sakine BAHÇECIOĞLU ${ }^{4}$ \\ (ID)
}

${ }^{1}$ Department of Chest Diseases, Faculty of Medicine, Gazi University, Ankara, Turkey

${ }^{1}$ Gazi Üniversitesi Tıp Fakültesi, Göğüs Hastalıkları Anabilim Dalı, Ankara, Türkiye

${ }^{2}$ Department of Family Medicine, Faculty of Medicine, Katip Celebi University, Izmir, Turkey

2 İzmir Katip Çelebi Üniversitesi Tıp Fakültesi, Aile Hekimliği Anabilim Dalı, Izmir, Türkiye

${ }^{3}$ Clinic of Chest Diseases, 82. Yil State Hospital, Rize, Turkey

${ }^{3}$ Rize 82. Yıl Devlet Hastanesi, Göğüs Hastalıkları Kliniği, Rize, Türkiye

${ }^{4}$ Clinic of Chest Diseases, Atatürk Chest Diseases and Chest Surgery Training and Research Hospital, Ankara, Turkey

${ }^{4}$ Ankara Atatürk Gögüs Hastalıkları ve Göğüs Cerrahisi Eğitim ve Araştırma Hastanesi, Gögüus Hastalıkları Kliniği, Ankara, Türkiye

\section{ABSTRACT}

Vitamin D status in hospitalized patients with chronic obstructive pulmonary disease

Introduction: Vitamin D deficiency and chronic obstructive pulmonary disease (COPD) are both world-wide health problems. Vitamin $D$ has known to be important in infectious pathologies. However, there are conflicting results in the role of vitamin D in COPD exacerbation. This study was design to evaluate the prevalence of vitamin D deficiency among patients with COPD exacerbation in relation with surrogate markers of exacerbation and long-term mortality in hospitalized patients with COPD.

Materials and Methods: 117 hospitalized COPD patients were included between January 2010 to June 2013. Information was obtained through the patients' records and the electronic database of the hospital. The patients who had on vitamin $D$ and/or calcium therapy, and who were suspected of asthma were excluded from the study.

Results: The study included 117 patients and none of them were on vitamin $D$ replacement on entry. The mean age was $67.95 \pm 9.8$ years. The number of male/female patients was 104/13. The mean forced expiratory volume in one second in percent predicted $\left(F E V_{1} \%\right.$ ) was $39.97 \pm 18.45$. One hundred fifteen patients had vitamin $D$ deficiency whereas only two patients had vitamin $D \geq 30 \mathrm{ng} / \mathrm{dL}$. Seventy nine $(69.5 \%)$ of the patients had severe vitamin $D$ deficiency $(<10 \mathrm{ng} / \mathrm{dL})$. The percentage of frequent exacerbators, patients 
who had microorganism growth and the median duration of hospital stay, mean FEV 1 and survival did not differ between the group of vitamin $D<$ or $\geq 10 \mathrm{ng} / \mathrm{dL}$. There was no meaningful correlation of vitamin D level and any of the surrogate markers of exacerbation.

Conclusion: Severe vitamin D deficiency is heavily prevalent in Turkish COPD patients. However, it did not have an association on exacerbation and long term survival.

Key words: Chronic obstructive pulmonary disease; exacerbation; vitamin D deficiency

\section{Öz}

\section{Hastanede yatan kronik obstrüktif akciğer hastalığı olan hastalarda D vitamini durumu}

Giriş: Kronik obstrüktif akciğer hastalı̆̆ı (KOAH)'nın ve D vitamini eksikliğinin her ikisi de dünya çapında sağlık sorunlarıdır. D vitamininin bulaşıcı patolojilerde önemli rolü olduğu bilinmektedir. Ayrıca, KOAH alevlenmesinde de D vitamininin rolü olduğu ile ilgili çelişkili sonuçlar vardır. Bu çalışma, KOAHılı hastalarda vitamin D eksikliğinin yaygınlığını; hastanede yatan KOAH'lı hastaların alevlenme belirteçleri ve uzun dönem mortalite ile D vitamini arasındaki ilişkiyi değerlendirmek için tasarlandı.

Materyal ve Metod: Ocak 2010-Haziran 2013 tarihleri arasında hastanede yatmış 117 KOAH hastası çalışmaya dahil edildi. Bilgilere hasta kayıtları ve hastanenin elektronik veri tabanı aracılığıyla ulaşıldı. D vitamini ve/veya kalsiyum tedavisi gören ve astım şüphesi alan hastalar çalışma dışı bırakıldı.

Bulgular: Çalışmaya dahil edilen 117 hastanın hiçbiri D vitamini replasmanı almamaktaydı. Ortalama yaş $67.95 \pm 9.8$ yıl idi. Erkek/ kadın hasta sayısı 104/13'tü. Zorlu ekspirasyonun birinci saniyesinde atılan volüm (FEV \%) $39.97 \pm 18.45$ idi. Yüz on beş hastada D vitamini eksikliği vardı, sadece iki hastanın D vitamini $\geq 30 \mathrm{ng} / \mathrm{dL}$ idi. Hastaların 79 (\%69.5)'unda ciddi D vitamini eksikliği $(<10$ $\mathrm{ng} / \mathrm{dL}$ ) vardı. D vitamini $10 \mathrm{ng} / \mathrm{dL}$ 'nin altında olan ve $10 \mathrm{ng} / \mathrm{dL}$ ve üzerinde olan gruplar arasında alevlenme sıklı̆̆ı, mikroorganizma üremesi, ortalama hastanede kalma süresi, ortalama FEV, ve sağkalım açısından farklıık saptanmadı. Vitamin D düzeyi ve alevlenmenin belirteçleri arasında anlamlı bir ilişki yoktu.

Sonuç: Türkiye'de KOAH hastalarında ciddi D vitamini eksikliği oldukça yaygındır. Ancak, bunun alevlenme ve uzun süreli sağkalım ile bir ilişkisi yoktur.

Anahtar kelimeler: Kronik obstrüktif akciğer hastalı̆̆ı; alevlenme; D vitamini eksikliği

\section{INTRODUCTION}

Vitamin D deficiency and chronic obstructive pulmonary disease (COPD) are both world-wide health problems leading severe morbidity and mortality particularly in countries with low socioeconomic status $(1,2)$. Under the ultraviolet B, Vitamin D is synthesized in skin $(3,4)$. Vitamin D exerts its action on calcium and phosphorus absorption which are essentials for cellular functions and musculoskeletal health $(3,4)$. In vitamin D deficiency, calcium and phosphorus absorption from the small intestine is impaired and only $10 \%$ of calcium and $50 \%$ of phosphorus can be absorbed. The well-known effects of vitamin $\mathrm{D}$ deficiency are rickets, osteomalacia, osteoporosis and muscle weakness $(3,4)$. A serum level of $10 \mathrm{ng} /$ $\mathrm{mL}(25 \mathrm{nmol} / \mathrm{L})$ of $25(\mathrm{OH})$ vitamin $\mathrm{D}$ is been considered to be the threshold for preventing rickets and osteomalacia, but the desirable level for many essential noncalcemic health benefit should be above 20-30 ng/mL (5). The US Endocrinology Society defined vitamin $\mathrm{D}$ deficiency as a blood $25(\mathrm{OH}) \mathrm{D}$ level below $20 \mathrm{ng} / \mathrm{mL}(50 \mathrm{nmol} / \mathrm{L})$ and vitamin $\mathrm{D}$ insufficiency when the level lies between 21-29 ng/
$\mathrm{mL}(52.5-72.5 \mathrm{nmol} / \mathrm{L})$. In the absence of adequate sun exposure, at least 800-1000 IU vitamin D per day may be needed to maintain $30 \mathrm{ng} / \mathrm{mL}$ blood level of vitamin D (5).

Vitamin D deficiency is mostly caused by inadequate exposure to sunlight and inadequate dietary intake. In order to have appropriate vitamin D production, direct sunlight exposure needs to be maintained for only 15 min twice a week (without wearing sunscreen) (6). Since there is a seasonal variation in sunlight, there is also a seasonal variation in serum vitamin D level which shows the highest level in summer and the lowest level in winter in the northern hemisphere (7). Apart from sun exposure, premature birth, pigmented skin, obesity, malabsorption, glucocorticoid usage and advanced age are known risk factors for vitamin D deficiency (8).

There has been an intense interest in the relation with vitamin D and lung functions and COPD (9-13). A recent study showed that vitamin $\mathrm{D}$ deficiency was more prevalent (up to $77 \%$ ) among COPD patients compared with smokers (31\%) (13). COPD patients 
could be more prone to develop vitamin D deficiency. Reduced sun exposure due to staying indoor, low food intake, aging, glucocorticoid usage could be the reasons of increased risk of vitamin $D$ deficiency in COPD patients $(14,15)$. Hence, there are studies investigating mechanistic relationship with vitamin $\mathrm{D}$ deficiency, vitamin D binding protein and the development of COPD (16). Copenhagen City Heart Study showed that low vitamin D level would increase the future risk of COPD (12).

The vitamin D deficiency in COPD could cause several remarkable effects. Increased risk of osteoporosis, increased risk of fracture, muscle weakness and falling are the best-known ones $(17,18)$.

Vitamin D is known antimycobacterial, antibacterial and antiviral effects through various mechanisms. Antimicrobial polypeptides such as cathelicidin are genetically under the control of vitamin $D$ response element (VDRE). Vitamin D has a profound role in orchestrating immune response. The exacerbation of COPD may be resulted by impaired innate response to pathogen followed by excessive adaptive immune response. Therefore, vitamin D could have an important role in infectious exacerbation in COPD (19). Several studies have shown inconsistent results in relation with vitamin D deficiency and COPD exacerbation and, a benefit of vitamin $D$ replacement in terms of preventing COPD exacerbation (20-23).

This study has been carried out to investigate; 1 ) the prevalence of vitamin D deficiency, 2) if there is any relation with serum vitamin $\mathrm{D}$ level to clinical and inflammatory parameters 3 ) the relation with longterm mortality with vitamin D deficiency in hospitalized patients with COPD.

\section{MATERIALS and METHODS}

\section{Subjects and Study Design}

This is a cross-sectional study carried out between January 2010 to August 2016. 117 consecutive hospitalized COPD patients were included between January 2010 to June 2013. The diagnosis of the COPD patients 8 was based on a previously done Pulmonary Function Test. Patients were followed until August 2016 to collect the data about all cause of mortality. All patients were admitted to the clinic with worsening of dyspnea and/or cough and sputum production. Information was obtained through the patients' records and the electronic database of the hospital. The patients who had on vitamin D and/or calcium therapy, and who were suspected of asthma were excluded from the study.

The admission which the data was collected, prebronchodilator pulmonary function tests (PFTs); comorbidities, the exacerbation history of previous year, the usage of long-term oxygen treatment (LTOT) or noninvasive mechanic ventilator (NIMV), the etiology of worsening symptoms, the type of infectious exacerbation, number of patients who grow microorganisms, plasma vitamin D level, C-reactive protein (CRP), erythrocyte sedimentation rate (ESR), and the readmission rate within 30 days after discharge had been recorded. All cause of mortality was assessed using death certification database in the first of August 2016.

\section{Diagnosis, Definitions and Evaluation Tools}

The diagnosis of COPD was established according to the Global Initiative for Obstructive Lung Disease (GOLD) Guideline in a stable condition (24). Accordingly, a forced expiratory volume in one second/forced vital capacity $\left(\mathrm{FEV}_{1} / \mathrm{FVC}\right)<0.7$ and a compatible medical history were required for the diagnosis (24).

Pulmonary function tests; were performed with Sensor Medics Vmax20 Spirometer in sitting position while wearing a nose clip. Three full inspiration and forced expiration maneuvers were performed according to the European Respiratory Society (ERS) Criteria. The recorded values were taken from the best of three forced expiratory measurements (25).

COPD exacerbation was defined as an increase of symptoms beyond the normal daily variability which need a treatment change. Exacerbations that need to be treated with oral corticosteroids and/or antibiotics were defined as moderate exacerbations. Exacerbation required hospitalization [either in ward or intensive care unit (ICU)] was defined as severe exacerbation. Two or more moderate/severe exacerbations per year were defined as frequent exacerbation (24). Infectious exacerbations were defined by Anthonisen's Criteria. According to this definition, the patient has to have at least one of the following three symptoms; increased dyspnea, increased sputum production and purulent sputum (26). Type I exacerbation (severe) is characterized by all of the three symptoms; Type II (moderate) is characterized by two of the three symptoms; Type III (mild) is characterized by only one of the three symptoms and at least one of 
symptoms related with upper airway infectious symptoms (26).

Comorbidities were recorded if it was proven by patient's self-declaration or by medical records. Additional lung conditions, such as pneumonia, pulmonary embolism, bronchiectasis and lung carcinoma, were defined by radiological findings and an appropriate clinical picture on the decision of attending doctors.

Plasma $25(\mathrm{OH})$ D levels; were measured by radioimmunoassay (DIA source, Belgium). Levels $\geq 30 \mathrm{ng} / \mathrm{dL}$ were defined as normal, levels between 20 to $29 \mathrm{ng} /$ $\mathrm{dL}$ were defined as insufficiency, levels below 19 were defined as deficiency. Levels below $10 \mathrm{ng} / \mathrm{dL}$ were defined as severe deficiency (5).

\section{Statistics}

Statistical analyses were perfomed using the SPSS software demo version 20. All variables were investigated using visual (histograms, probability plots) and analytical methods (Kolmogorov Smirnov/ShapiroWilk's test) to determine whether or not they are normally distributed. Descriptive analyses were presented as means ( \pm standard deviations) and medians (min-max). Student's t test, Mann-Whitney $U$ test and chi-square test were used to compare variables between study groups. The correlation coefficients were calculated with using Pearson or Spearman coefficient where appropriate.

The effect of the level of vitamin D on survival of COPD patients in exacerbation were investigated using the log rank test. The Kaplan-Meier survival estimates were calculated. Seasonal change of the vitamin D was evaluated with Kruskal-Wallis test. Significance was determined at 5\% level.

\section{RESULTS}

117 patients hospitalized for worsening of COPD has been included in the study. The majority of the patients were men $(M / F=104 / 13)$. The mean age was $67.95 \pm 9.8$ years. One hundred five patients were heavy smokers. The median pack/year was 50 and the $38 \%$ of patient had more than 3 comorbidities. The median number of exacerbation in previous year was 1 and $49 \%$ of the patients were frequent exacerbators. The mean $\mathrm{FEV}_{1}$ was $38.72 \pm 16.48$. The mean partial oxygen pressure $\left(\mathrm{PO}_{2}\right)$ was $58.11 \pm 12.45$. The median CRP was 11. The demographic, clinical, functional and laboratory parameters were summa- rized in Table 1 and 2. Majority of patients (80\%) were hospitalized for infectious COPD exacerbation which $61.8 \%$ were Anthonisen type one. $70 \%$ of the patients did not grow any microorganism. $37 \%$ of the patients were on flourokinolon and $14.9 \%$ were on amoxiciline clavulonate and $8 \%$ were on clarithromycin.

Ninety-seven point eight \% patients had vitamin D deficiency. Sixty-seven point five \% of the patients had vitamin D level under $10 \mathrm{ng} / \mathrm{dL}$. Only two patients had normal vitamin D (> $30 \mathrm{ng} / \mathrm{dL}$.) Vitamin $\mathrm{D}$ level was assessed according to the 4 seasons. The mean Vitamin D level in winter, spring, summer, autumn were as follows; 6.15 (2.4-26.4), 6 (1.7-26), 9.55 (2-32), 9.5 (4.1-37). There was statistical difference and the difference is resulted from the difference of spring and autumn; winter and autumn $(p=$ 0.027; 0.049, respectively).

There was no difference regarding demography, functional parameters, comorbidity number, number of exacerbation, duration of hospitalization, CRP, ESR, production of microorganism with vitamin $\mathrm{D}$ level below or higher $10 \mathrm{ng} / \mathrm{dL}$ (Table 3). Correlation analysis revealed that vitamin $\mathrm{D}$ is weakly correlated with the number of the comorbidities $(r=0.189 ; p=0.045)$ in which we don't have an explanation. None of the other variables were correlated with vitamin D level. All scores showed moderate positive correlation with body mass index (BMI) (Table 4).

Patients were followed for 80 months. Survival analysis showed 67.07 median survival. There was no difference on the basis of vitamin $\mathrm{D}$ level on survival (Table 5). Kaplan Meier curves showed there is no difference on survival in association with vitamin D level (Figure 1).

\section{DISCUSSION}

This study showed that vitamin D deficiency was heavily prevalent in COPD in exacerbations. However, the level did not have an influence on surrogate markers of exacerbation and long term mortality.

Vitamin D deficiency is a preventable health epidemic. In European countries, the rate of deficiency is between 2-30\% (27). Although Turkey is a sunshine country, the level of vitamin D in the population is quite low. Thirty-three \% of elderly people, had a vitamin D level under $15 \mathrm{ng} / \mathrm{dL}$ in Turkish study (28). In 209 household people over 20 years in Aegean region $75 \%$ of the people had a high prevalence of 
Table 1. Demographic and clinical data of patients

\begin{tabular}{|c|c|}
\hline & All patients \\
\hline Age $($ mean $\pm \mathrm{SD})$ years & $67.95 \pm 9.8$ \\
\hline \multicolumn{2}{|l|}{$\operatorname{Sex}(\%)$} \\
\hline Female & $13(11.1)$ \\
\hline Male & $104(88.9)$ \\
\hline Body mass index $(\mathrm{BMI})($ mean $\pm \mathrm{SD})$ & $25.96 \pm 6.07$ \\
\hline Smoking never/heavy & $12 / 105$ \\
\hline Cigarette (pack/year) [median (min-max)] & $50(1-200)$ \\
\hline Duration of COPD (years) (mean \pm SD) & $9.75 \pm 7.31$ \\
\hline The number of comorbidities [median (min-max)] & $2(0-7)$ \\
\hline Number of patients who had more than 3 comorbidities (\%) & $38(33.6)$ \\
\hline Number of exacerbation in the previous year [median (min-max)] & $1(0-8)$ \\
\hline Number of frequent exacerbators (\%) & $49(49)$ \\
\hline Number of patients who admitted ICU (\%) & $19(17.7)$ \\
\hline Number of entubated patients (\% of patients) & $8(7.5)$ \\
\hline Antibiotic users in the previous year of index admission ( $\%$ of patients) & $81(73.2)$ \\
\hline Readmission rate in one month after discharge (\% of patients) & $33(35.9)$ \\
\hline Number of patients who are on LTOT (\%) & $43(38.7)$ \\
\hline Number of patients who are on NIMV (\%) & $14(13.5)$ \\
\hline The etiology of worsening symptoms (\%) & $(\mathrm{n}=110)$ \\
\hline Heart failure & $10(9.1)$ \\
\hline Irregular drug use & $8(7.3)$ \\
\hline Pulmonary thromboembolism & $2(1.8)$ \\
\hline Pneumonia & $12(10)$ \\
\hline Infectious COPD exacerbation & $89(80)$ \\
\hline The type of COPD exacerbation (\%) & $(n=89)$ \\
\hline Type 1 & $55(61.8)$ \\
\hline Type 2 & $16(18.0)$ \\
\hline Type 3 & $18(20.2)$ \\
\hline
\end{tabular}

vitamin D deficiency (29). The most cited explanation of the low level would be the clothing habit in Turkey. People tend to wear long sleeves in many region and in summer time people tend to stay indoor to prevent sunlight exposure. In a recent study carried out 90 Turkish adults, vitamin D deficiency was found to be related with obesity and metabolic syndrome (30).

Vitamin D deficiency has been found to be very common in COPD patients in comparison to normal smokers (13). COPD patients showed 2 times more risk of being vitamin $\mathrm{D}$ deficient compared to controls. The determinants of vitamin $\mathrm{D}$ deficiency were found to be worse airflow limitation, obesity and current smoking (31). In a cross sectional study, a relationship was found between dietary vitamin D intake and $\mathrm{FEV}_{1}, \mathrm{FEV}_{1} / \mathrm{FVC}$ and a negative association with vitamin $D$ intake and the presence of COPD. However, there was no association between the baseline serum level of vitamin $\mathrm{D}$ and $\mathrm{FEV}_{1}$ or presence of COPD (32). In the Lung Health Study 3 cohort, baseline $25(\mathrm{OH}) \mathrm{D}$ levels were compared between rapid and slow lung function decliners and there was no significant difference. Hence, there was no significant difference in baseline $25(\mathrm{OH}) \mathrm{D}$ levels between rapid and slow decliners (33). However, in the Norway cohort, vitamin D deficient patients $(<$ $10 \mathrm{ng} / \mathrm{mL}$ ) had greater $\mathrm{FEV}_{1}$ decline (34).

There are few studies regarding vitamin $\mathrm{D}$ level and the COPD exacerbation $(20,21)$. Kunisaki et al. did 


\section{Table 2. Functional and laboratory parameters of patients}

\begin{tabular}{|c|c|}
\hline Variables & Mean \pm SD \\
\hline $\mathrm{FEV}_{1} / \mathrm{FVC}$ & $52.57 \pm 11.34$ \\
\hline $\mathrm{FEV}_{1} \%$ & $38.72 \pm 16.48$ \\
\hline FVC $\%$ & $55.87 \pm 16.07$ \\
\hline $\mathrm{PO}_{2}$ & $58.11 \pm 12.45$ \\
\hline $\mathrm{PCO}_{2}$ & $43.39 \pm 11.07$ \\
\hline Hemoglobin (g/dL) (HGB) & $14.03 \pm 1.91$ \\
\hline Hematocrit $(\%)(\mathrm{HCT})$ & $42.04 \pm 7.57$ \\
\hline C-reactive protein (CRP) [median (min-max)] & $11(0-450)$ \\
\hline Erythrocyte sedimentation rate (ESR) [median (min-max)] & $25(0-98)$ \\
\hline Plasma vitamin D level [median (min-max)] & $7.1(1.7-37)$ \\
\hline \multicolumn{2}{|l|}{ Distribution of vit D deficiency and insufficiency, $\mathrm{n}(\%)$} \\
\hline$<10 \mathrm{ng} / \mathrm{dL}$ & $79(67.5)$ \\
\hline $10-19 \mathrm{ng} / \mathrm{dL}$ & $27(23.1)$ \\
\hline $20-29 \mathrm{ng} / \mathrm{dL}$ & $9(7.7)$ \\
\hline$\geq 30 \mathrm{ng} / \mathrm{dL}$ & $2(1.7)$ \\
\hline
\end{tabular}

not find any association between the vitamin $D$ level and the number of the exacerbation (20). Quint et al. did not find any association with the number of exacerbation and the susceptibility of human rhinovirus (21). In a study carried out in exacerbated patients, the entry level of vitamin D was correlated with pulmonary function tests, dyspnea level, length of hospital-stay but not the exacerbation number in the previous year (35). In an Italian study conducted in 97 COPD patients, vitamin D deficiency was found to be related with frequent exacerbation and hospitalization number in the previous year of index date (36). In a longitudinal study, $77 \%$ of the COPD patients showed vitamin D deficiency and there was no difference in exacerbation rate and mortality according to baseline level of vitamin D (37). In a Norway study, 426 COPD patients was followed for 3 years and there was no relation with the baseline vitamin $\mathrm{D}$ level and exacerbation rate and mortality (34).

In our study, compared with previous Turkish studies and COPD studies, baseline vitamin D level was remarkably low if not the lowest. In Italian study, the severe deficiency level $(<10 \mathrm{ng} / \mathrm{dL})$ was $36 \%$ and the total vitamin D deficient COPD patients were $96 \%$. In Norway cohort, the severe deficiency rate was only \%6.5 (34). In Janssens' study, the prevalence of vitamin D deficiency increased with the COPD GOLD stage which was over $70 \%(<20 \mathrm{ng} / \mathrm{dL})$ in severe COPD (13). In 2013 critically ill Turkish patients admitted to ICU located in the same institute and using the same vitamin D measurement method, the median vitamin D level was 13.75 which was almost double of vitamin D level in our study $(7.1 \mathrm{ng} /$ $d L)$ (38). Although Turkey is sunshine country, people tend to stay indoor and wear long sleeve clothing. In elderly and sick patients, there are additional well known risk factors including physical inactivity, smoking, obesity, malnutrition, skin phenotype and genetics (39). Hence, there is no fortified food in Turkey. Another explanation would be the vitamin D assessment method. Different cut-off and different measurement method would cause interpretation problems. Seasonal differentiation is also very important in the results. In our study we also obtained significant differences between both spring-autumn and winter-autumn. Theoretically and importantly the measurements were done during the hospitalization, a period that patients had respiratory insufficiency and under the influence of several drugs including systemic steroids and antibiotics, which could lead interactions in the metabolism of vitamin D.

As far as we know the current study is the first study performed in COPD population in Turkey. Hence, it was conducted in hospitalized COPD patients aiming the relation with vitamin $\mathrm{D}$ level and different clinical and laboratory parameters of COPD exacerbation. With this respect, only the Bulgarian study 
Table 3. The features of patients with or without severe vitamin D deficiency

\begin{tabular}{|c|c|c|c|}
\hline & Vitamin $\mathrm{D}<10 \mathrm{ng} / \mathrm{dL}$ & Vitamin $\mathrm{D} \geq 10 \mathrm{ng} / \mathrm{dL}$ & \\
\hline & Mean \pm SD & Mean \pm SD & $\mathbf{p}$ \\
\hline $\operatorname{Age}^{\mathrm{a}}$ & $67.06 \pm 10.07$ & $69.84 \pm 9.79$ & 0.161 \\
\hline Body mass index $(\mathrm{BMI})^{\mathrm{a}}$ & $26.02 \pm 6.36$ & $25.83 \pm 5.52$ & 0.900 \\
\hline Median n of cigarette (pack/year) ${ }^{b}$ & $55(1-150)$ & $50(10-200)$ & 0.991 \\
\hline Median duration of COPD (years) ${ }^{b}$ & $7(1-40)$ & $9(1-28)$ & 0.193 \\
\hline Median $\mathrm{n}$ of comorbidity ${ }^{b}$ & $2(0-7)$ & $2(1-7)$ & 0.105 \\
\hline Median $n$ of exacerbation in the previous year ${ }^{b}$ & $1(0-7)$ & $2(1-6)$ & 0.074 \\
\hline Median duration of hospital stay in admission $(\text { day })^{b}$ & $9(1-33)$ & $7(3-23)$ & 0.368 \\
\hline Number of patients who had readmission $(\%)^{C}$ & $22(35.5)$ & $11(36.7)$ & 0.912 \\
\hline Number of frequent exacerbators in the previous year $(\%)^{C}$ & $10(15.2)$ & $10(32.3)$ & 0.052 \\
\hline Number of patients admitted ICU in the previous year $(\%)^{\mathrm{C}}$ & $14(18.9)$ & $5(15.2)$ & 0.638 \\
\hline Number of having more than 3 comorbidities $(\%)^{\mathrm{C}}$ & $22(28.6)$ & $16(44.4)$ & 0.096 \\
\hline Number of patients on LTOT $(\%)^{c}$ & $27(35.5)$ & $16(45.7)$ & 0.306 \\
\hline Number of patients on NIMV $(\%)^{\mathrm{C}}$ & $8(11.4)$ & $6(17.6)$ & 0.383 \\
\hline $\mathrm{FEV}_{1} / \mathrm{FVC}^{\mathrm{a}}$ & $53.13 \pm 11.82$ & $51.39 \pm 10.33$ & 0.472 \\
\hline $\mathrm{FEV}_{1} \%^{\mathrm{a}}$ & $39.97 \pm 18.45$ & $36.09 \pm 11.10$ & 0.191 \\
\hline $\mathrm{FVC} \%{ }^{\mathrm{a}}$ & $56.81 \pm 16.92$ & $53.91 \pm 14.17$ & 0.396 \\
\hline $\mathrm{PO}_{2}{ }^{\mathrm{a}}$ & $57.31 \pm 12.95$ & $59.95 \pm 11.24$ & 0.379 \\
\hline $\mathrm{PCO}_{2}{ }^{\mathrm{a}}$ & $43.68 \pm 11.74$ & $42.70 \pm 9.49$ & 0.713 \\
\hline Hemoglobin $^{\mathrm{a}}$ & $14.10 \pm 1.87$ & $13.86 \pm 1.99$ & 0.546 \\
\hline Hematocrit $^{\mathrm{a}}$ & $42.41 \pm 8.50$ & $41.28 \pm 5.21$ & 0.480 \\
\hline Median C-reactive protein ${ }^{b}$ & $7.3(1-450)$ & $12.1(1-284)$ & 0.997 \\
\hline Median erythrocyte sedimentation rate ${ }^{b}$ & $27(1-98)$ & $20(3-86)$ & 0.321 \\
\hline Number of patients who grow microorganismsn $(\%)^{\mathrm{C}}$ & $26(37.1)$ & $14(40.0)$ & 0.776 \\
\hline
\end{tabular}

was alike to our study (35). In Bulgarian study, the mean level of vitamin D was $31.97 \mathrm{nmol} / \mathrm{L}$ and $40.8 \%$ of the patients had vitamin D level below 25 $\mathrm{nmol} / \mathrm{L}$ although the prevalence of vitamin $\mathrm{D}$ deficiency was $75 \%$. Vitamin D level was correlated with modified Medical Research Council (mMMRC), lung function but not the number of exacerbations in the previous year. Our study was not in concordance with that study showing no association with lung function or exacerbation numbers in previous year. Additionally, there were no association with vitamin $D$ level and any infection related parameters including bacterial growth, CRP, ESR or the severity of current exacerbation including hypoxemia, length of hospital stay and early readmission rate. These parameters were looked for the first time in the literature. Negative results were in concordance with some of the previous studies $(20,21,32,34,37)$.
However, there are positive studies showing association of vitamin D level and lung functions and/or exacerbation numbers (34-36). There are also conflicting results in the effect of vitamin D supplementation in preventing COPD exacerbations. Carefully design randomized controlled studies will clarify the issues. Two studies; lung vital and prevention of exacerbations in patients with COPD and vitamin D deficiency through vitamin D supplementation (PRECOVID) are already on the pipeline to answer the remained questions $(40,41)$.

Our study is a retrospective, single center study that depends on hospital records which may cause limitations, selection bias and missing values. The number of patients is relatively small and there is no control group. However, the study provides new insight in the field that has not been looked at before. The study is carried out during exacerbation which allows us to 
Table 4. Correlations between vitamin D and functional and laboratory parameters

\begin{tabular}{|c|c|c|c|}
\hline & \multicolumn{3}{|c|}{ Vitamin D } \\
\hline & $\mathbf{n}$ & Correlation coefficient & $\mathbf{p}$ \\
\hline Age & 117 & 0.102 & 0.275 \\
\hline Body mass index (BMI) & 73 & 0.138 & 0.243 \\
\hline Cigarette (pack/year) & 104 & -0.067 & 0.497 \\
\hline Duration of COPD (years) & 111 & 0.061 & 0.524 \\
\hline The number of comorbidities & 113 & 0.189 & 0.045 \\
\hline Number of exacerbation in the previous year & 100 & -0.057 & 0.575 \\
\hline Duration of hospitalization in the index admission (days) & 98 & -0.067 & 0.511 \\
\hline $\mathrm{FEV}_{1} / \mathrm{FVC}$ & 102 & -0.056 & 0.579 \\
\hline $\mathrm{FEV}_{1} \%$ & 102 & 0.005 & 0.960 \\
\hline FVC $\%$ & 102 & -0.045 & 0.652 \\
\hline $\mathrm{PO}_{2}$ & 83 & 0.127 & 0.253 \\
\hline $\mathrm{PCO}_{2}$ & 83 & -0.026 & 0.817 \\
\hline Hemoglobin & 106 & -0.112 & 0.254 \\
\hline Hematocrit & 103 & -0.078 & 0.450 \\
\hline C-reactive protein & 101 & 0.008 & 0.940 \\
\hline Erythrocyte sedimentation rate & 92 & -0.058 & 0.586 \\
\hline
\end{tabular}

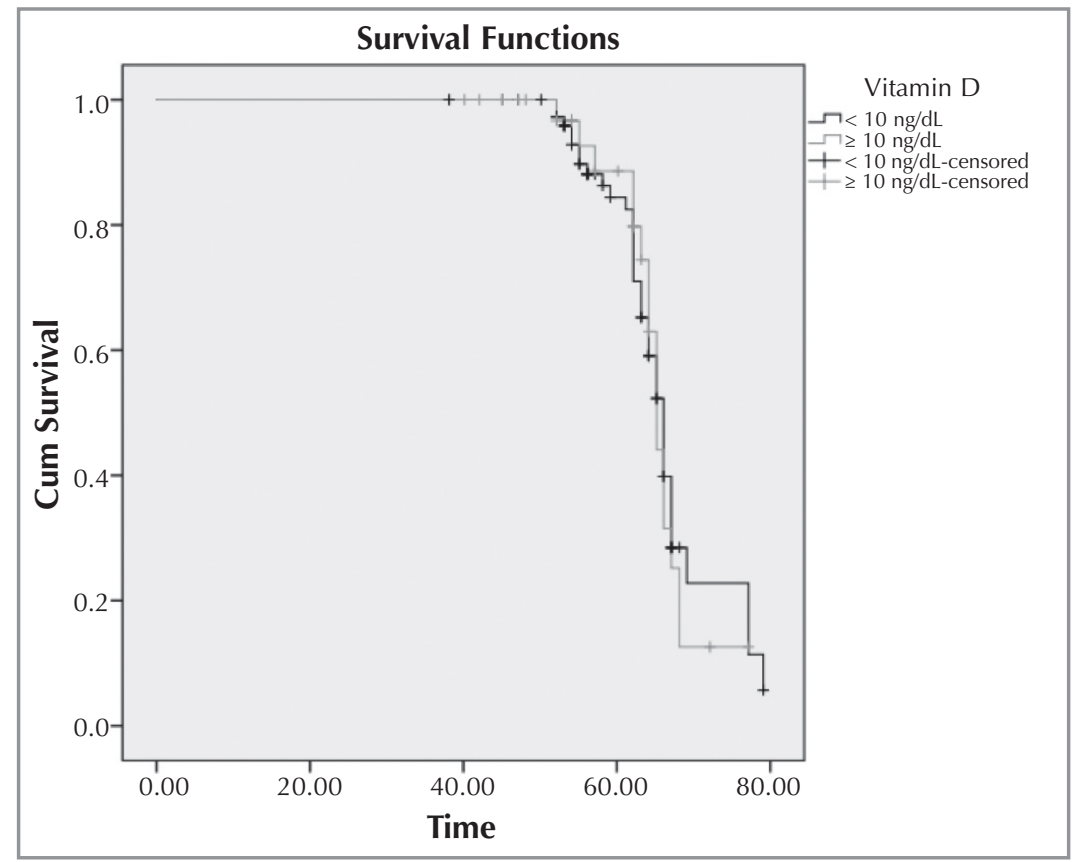

Figure 1. Survival curve for the vitamin $D$ level. Survival time for vit $\mathrm{D}<10 \mathrm{ng} / \mathrm{dL} 66.531 \pm 1.227$; vit $\mathrm{D} \geq 10 \mathrm{ng} / \mathrm{dL} 65.649 \pm 1.271 ; \mathrm{p}=$ 0.880 . 
investigate the relation with vitamin $\mathrm{D}$ and clinical and laboratory parameters during exacerbations. The follow up data is complete for all patient except two of them giving a strength for mortality data.

In conclusion, there are both positive and negative studies in relation with vitamin D and COPD exacerbation. Our study has supported the negative results in term of exacerbation number, functional parameters, surrogate markers of exacerbation and mortality.

\section{CONFLICT of INTEREST}

The authors report no conflicts of interest.

\section{AUTHORSHIP CONTRIBUTIONS}

\author{
Concept/Design: NK, TKA
}

Analysis/Interpretation: EMK, SB

Data Acquisition: TKA, SB, EMK

Writting: SB, EMK, TKA

Critical Revision: NK, EMK

Final Approval: NK, EMK

\section{REFERENCES}

1. Peterlik M, Boonen S, Cross HS, Lamberg-Allardt C. Vitamin $D$ and calcium insufficiency-related chronic diseases: an emerging world-wide public health Pproblem. Int J Environ Res Public Health 2009;6:2585-607.

2. Vestbo J, Hurd SS, Agusti AG, Jones PW, Vogelmeier C, Anzueto A, et al. Global strategy for the diagnosis, management, and prevention of chronic obstructive pulmonary disease GOLD executive summary. Am J Respir Crit Care Med 2013;187(4):347-65.

3. Lips P. Vitamin D physiology. Progress in Biophysics and Molecular Biology 2006;92(1):4-8.

4. Holick MF. Resurrection of vitamin D deficiency and rickets. J Clin Invest 2006;116:2062-72.

5. Holick MF, Binkley NC, Bischoff-Ferrari HA, et al. Evaluation, treatment, and prevention of vitamin $D$ deficiency: an endocrin society clinical practice guideline. I Clin Endocrinol Metab 2011;96:1911-30.

6. Quint JK, Wedzicha JA. Is vitamin D deficiency important in the natural history of COPD? Thorax 2010;65(3):192-4.

7. Hypponen E, Power C. Hypovitaminosis D in British adults at age $45 \mathrm{y}$ : nation wide cohort study of dietary and lifestyle predictors. Am J Clin Nutr 2007;85:860-8.

8. Hughes DA, Norton R. Vitamin $D$ and respiratory health. Clin Experiment Immunol 2009;158:20-5.

9. Persson LJP, Aanerud M, Hiemstra PS, Hardie JA, Bakke PS, Eagan TML. Chronic obstructive pulmonary disease is associated with low levels of vitamin D. PLoS One 2012;7(6):e38934.
10. Zhu B, Zhu B, Xiao C, Zheng Z. Vitamin D deficiency is associated with the severity of COPD: a systematic review and meta-analysis. Int J COPD 2015;10:1907-16.

11. Skaaby T, Husemoen $L L$, Thuesen BH, Pisinger $C$, Jorgensen $T$, Fenger RV, et al. Vitamin D status and chronic obstructive pulmonary disease: a prospective general population study. PLoS One 2014;9(3):e90654.

12. Shoaib A, Lange P, Bojesen SE, Freiberg IJ, Nordestgaard $B G$. Plasma 25-hydroxyvitamin D, lung function and risk of chronic obstructive pulmonary disease. Thorax 2014;69:24-31.

13. Janssens W, Bouillon R, Claes B, Carremans C, Lehouck $A$, Buysschaert $I$, et al. Vitamin $D$ deficiency is highly prevalent in COPD and correlates with variants in the Vitamin D-binding gene. Thorax 2010;65:215-20 [PubMed: 19996341].

14. Janssens W, Lehouck A, Carremans C, Bouillon R, Mathieu $C$, Decramer M. Vitamin $D$ beyond bones in chronic obstructive pulmonary disease. Time to Act. Am / Respir Crit Care Med 2009; 179:630-6.

15. Holick MF. Vitamin D deficiency. $N$ Engl J Med 2007; 357:266-81

16. Chishimba L, Thickett DR, Stockley RA, Wood AM. The vitamin $D$ axis in the lung: a key role for vitamin D-binding protein. Thorax 2010;65:456-62.

17. Inoue D, Watanabe R, Okazaki R. COPD and osteoporosis: links, risks, and treatment challenges. Int I COPD 2016;11:637-48.

18. Cielen N, Maes K, Gayan-Ramirez G. Musculoskeletal disorders in COPD. Bio Med Res Intern 2014;2014:965764.

19. Pfeffer PE, Hawrylowicz CM. Vitamin D and lung disease. Thorax 2012;67:1018-20.

20. Kunisaki KM, Niewoehner DE, Connett JE. Vitamin D levels and risk of acute exacerbations of chronic obstructive pulmonary disease. A prospective cohort study. Am I Respir Crit Care Med 2011;185(3):286-90

21. Quint JK, Donaldson GC, Wassef N, Hurst JR, Thomas M, Wedzicha JA. 25-hydroxyvitamin D deficiency, exacerbation frequency and human rhinovirus exacerbations in chronic obstructive pulmonary disease. BMC Pulm Med 2012;12:28.

22. Martineau AR, James WY, Hooper RL, Barnes NC, Jolliffe $D A$, Greiller $C L$, et al. Vitamin D3 supplementation in patients with chronic obstructive pulmonary disease (ViDiCO): a multicentre, double-blind, randomised controlled trial. Lancet Respir Med 2015;3:120-30.

23. Lehouck A, Mathieu C, Carremans C, Baeke F, Verhaegen J, Van Eldere J, et al. High doses of vitamin D to reduce exacerbations in chronic obstructive pulmonary disease a randomized trial. Ann Intern Med 2012;156:105-14.

24. Global Initiative for Chronic Obstructive Lung Disease. Global Strategy for the Diagnosis, Management, and Prevention of Chronic Obstructive Pulmonary Disease 2011. http://www.goldcopd.com/Guideline. 
25. Miller MR, Crapo R, Hankinson J, Brusasco V, Burgos $F$, Casaburi $R$, et al. General considerations for lung function. Series "ATS/ERS Task Force: Standardisation of Lung Function Testing". Eur Respir J 2005;26:153-61.

26. Anthonisen NR, Manfreda J, Warren CP, Hershfield ES, Harding GK, Nelson NA. Antibiotic therapy in exacerbations of chronic obstructive pulmonary disease. Ann Intern Med 1987;106:196-204.

27. Lips P. Vitamin D status and nutrition in Europe and Asia. Journal of Steroid Biochemistry\&Molecular Biology 2007; 103:620-5.

28. Atli T, Gullu S, Uysal AR, Erdogan G. The prevalence of vitamin $D$ deficiency and effects of ultraviolet light on vitamin D levels in elderly Turkish population. Archives of Gerontology and Geriatrics 2005;40(1):53-60.

29. Hekimsoy Z, Dinc G, Kafesciler S, Onur E, Guvenc Y, Pala T. Vitamin D status among adults in the Aegean region of Turkey. BMC Public Health 2010;10:782.

30. Tosunbayraktar G, Bas M, Kut A, Buyukkaragoz AH. Low serum 25(OH)D levels are associated to higher BMI and metabolic syndrome parameters in adult subjects in Turkey. Afri Health Sci 2015;15(4):1161-9.

31. Persson LJP, Aanerud M, Hiemstra PS, Hardie JA, Bakke PS, Eagan TML. Chronic obstructive pulmonary disease is associated with low levels of vitamin D. PloS One 2012;7(6):e38934.

32. Shaheen SO, Jameson KA, Robinson SM, Boucher BJ, Syddall HE, Sayer $A A$, et al. Relationship of vitamin $D$ status to adult lung function and COPD. Thorax 2011;66:692-8.

33. Kunisaki KM, Niewoehner DE, Singh RJ, Connett JE. Vitamin D status and longitudinal lung function decline in the lung health study. Eur Respir J 2011;37(2):238-43.

34. Persson LIP, Aanerud M, Hiemstra MS, Michelsen $A E$, Ueland $T$, Hardie $J A$, et al. Vitamin $D$, vitamin $D$ binding protein, and longitudinal outcomes in COPD. PLoS One 2015;10(3):e0121622.
35. Mekov E, Slavova Y, Tsakova A, Genova M, Kostadinov D, Minchev $D$, et al. Vitamin $D$ deficiency and insufficiency in hospitalized COPD patients. PLoS One 2015;10(6):e0129080.

36. Malinovschi A, Masoero $M$, Bellocchia $M$, Ciuffreda $A$, Solidoro P, Mattei A, et al. Severe vitamin D deficiency is associated with frequent exacerbations and hospitalization in COPD patients. Respiratory Research 2014; 15:131.

37. Puhan MA, Siebeling L, Frei A, Zoller M, Bischoff-Ferrari $H$, Ter Riet G. No association of 25-hydroxyvitamin D with exacerbations in primary care patients with COPD. Chest 2014; 145(1):37-43.

38. Turkoglu M, Aygencel G, Dizbay M, Tuncel AF, Candir BS, Bildaci $Y D$, et al. Is vitamin $D$ deficiency associated with development of Acinetobacter baumannii infections in critically ill patients? J Crit Care 2013;28:735-40.

39. Lucasa RM, Ponsonbyb AN, Deara K, Valeryc PC, Taylord $B$, Van der Meid I, et al. Vitamin D status: multifactorial contribution of environment, genes and other factors in healthy Australian adults across a latitude gradient. Journal of Steroid Biochemistry \& Molecular Biology 2013;136:300-8.

40. Gold DR, Litonjua AA, Vincent J, Carey VJ, Manson JE, Buring JE, et al. Lung VITAL: Rationale, design, and baseline characteristics of an ancillary study evaluating the effects of vitamin $D$ and/or marine omega-3 fatty acid supplements on acute exacerbations of chronic respiratory disease, asthma control, pneumonia and lung function in adults. Contemporary Clinical Trials 2016;47:185-95.

41. Rafiq R, Aleva FE, JSchrumpf JA, Heijdra YF, Taube C, Daniels JMA, et al. Prevention of exacerbations in patients with COPD and vitamin $D$ deficiency through vitamin $D$ supplementation (PRECOVID): a study protocol. BMC Pulmonary Medicine 2015;15:106. 